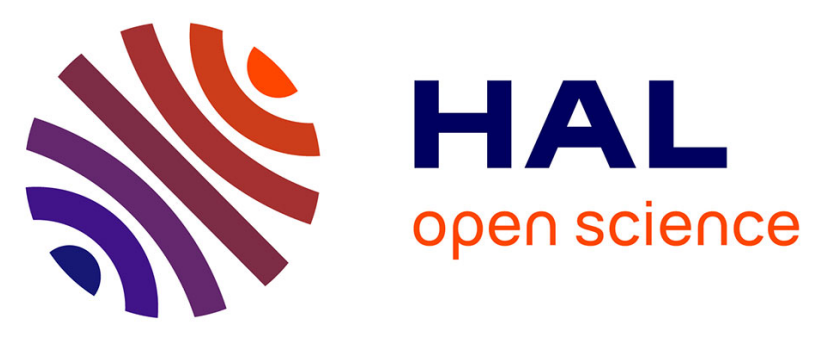

\title{
How High Concentrations of Proteins Stabilize the Amorphous State of Calcium Orthophosphate: A Solid-State Nuclear Magnetic Resonance (NMR) Study of the Casein Case
}

Paulo Peres de Sa Peixoto Junior, Juliana Valle Costa Silva, Guillaume

Laurent, Marc Schmutz, Daniel Thomas, Antoine Bouchoux, Geneviève

Gésan-Guiziou

\section{- To cite this version:}

Paulo Peres de Sa Peixoto Junior, Juliana Valle Costa Silva, Guillaume Laurent, Marc Schmutz, Daniel Thomas, et al.. How High Concentrations of Proteins Stabilize the Amorphous State of Calcium Orthophosphate: A Solid-State Nuclear Magnetic Resonance (NMR) Study of the Casein Case. Langmuir, 2017, 33 (5), pp.1256-1264. 10.1021/acs.langmuir.6b04235 . hal-01462797

\author{
HAL Id: hal-01462797 \\ https://hal.science/hal-01462797
}

Submitted on 4 Jul 2017

HAL is a multi-disciplinary open access archive for the deposit and dissemination of scientific research documents, whether they are published or not. The documents may come from teaching and research institutions in France or abroad, or from public or private research centers.
L'archive ouverte pluridisciplinaire $\mathbf{H A L}$, est destinée au dépôt et à la diffusion de documents scientifiques de niveau recherche, publiés ou non, émanant des établissements d'enseignement et de recherche français ou étrangers, des laboratoires publics ou privés. 


\title{
How high concentrations of proteins stabilize the amorphous state of calcium orthophosphate: a solid-state NMR study of the
}

\section{casein case}

\author{
Paulo D. S. Peixoto, ${ }^{1,2}$ Juliana V. C. Silva, ${ }^{1,2}$ Guillaume Laurent ${ }^{3}$, Marc Schmutz ${ }^{4}$, Daniel Thom- \\ $\mathrm{as}^{5}$, Antoine Bouchoux ${ }^{1,2, @}$, Geneviève Gésan-Guiziou ${ }^{1,2}$ \\ ${ }^{1}$ INRA, UMR1253 Science et Technologie du Lait et de l'CEuf, 65 rue de saint Brieuc, 35000 Rennes,
} France

${ }^{2}$ AGROCAMPUS OUEST, UMR1253, 65 rue de saint Brieuc, 35000 Rennes, France

${ }^{3}$ Sorbonne Universités, UPMC Paris 6, CNRS, Collège de France, Laboratoire de Chimie de la Matière Condensée de Paris (LCMCP), 11 place Marcelin Berthelot, 75005, Paris, France.

${ }^{4}$ Institut Charles Sadron, CAMPUS CNRS, 23 rue du LOESS, BP 84047, 70034, Strasbourg, France.

${ }^{5}$ Team Translation and Folding, Université de Rennes 1, UMR CNRS 6290 IGDR, Campus de Beaulieu, 35000 Rennes, France

${ }^{\circledR}$ Present address: LISBP, CNRS, INRA, INSAT, Université de Toulouse, 31400, Toulouse, France KEYWORDS. Amorphous Calcium Phosphate, phosphorylated proteins, casein, confinement, molecular concentration.

ABSTRACT: Understanding how proteins stabilize Amorphous Calcium ortho-Phosphate (ACP) phases is of great importance in biology and for pharmaceutical or food applications. Until now, most of the former investigations about ACP-protein stability and equilibrium were performed in conditions where ACP colloidal nanoclusters are surrounded by low to moderate concentrations of peptides or proteins (15$\left.30 \mathrm{~g} . \mathrm{L}^{-1}\right)$. As a result, the question of ACP-protein interactions in highly concentrated protein systems has clearly been overlooked, whereas it corresponds to actual industrial conditions such as drying or membrane filtration in the dairy industry for instance. In this study, the structure of an ACP phase is monitored in association with one model phosphorylated protein (casein) using solid state NMR (ssNMR) at two conditions of high protein concentration (300 and 400 g.L $\mathrm{L}^{-1}$ ). At both concentrations and at $25^{\circ} \mathrm{C}$, it is found that the caseins maintain the mineral phase in an amorphous form with no detectable influence on its structure or size. Interestingly, and in both cases, a significant amount of the non-phosphorylated side chains interacts with ACP through $\mathrm{H}$-bonds. The number of these interacting side-chains is found to be higher at the highest casein concentration. At $45^{\circ} \mathrm{C}$, which is a destabilizing temperature of ACP in protein-free conditions, the amorphous structure of the mineral phase is partially transformed at 300
g.L $\mathrm{L}^{-1}$ while it remains almost intact at $400 \mathrm{~g} . \mathrm{L}^{-1}$. These results thus clearly indicate that rising the concentration of proteins favor protein-ACP interactions and stabilize the ACP clusters more efficiently.

\section{INTRODUCTION}

In order to fulfill their biological functions, many biofluids such as milk, blood or saliva have to contain concentrations of calcium and phosphate that largely exceed the limits of solubility. ${ }^{1}$ In such fluids, Ca and P are usually not present in the form of a crystalline phase, but are rather sequestered into amorphous calcium phosphate clusters (ACP clusters) that are highly stable and do not mature into more crystalline phases. 1,2,3,4 These ACP nanoclusters are equilibrium particles in which the mineral core is stabilized by a shell made of peptides or proteins that typically are phosphorylated and tend to have intrinsically disordered structures. ${ }^{4,5}$

Many studies have investigated the mechanisms of ACP stabilization by phosphorylated proteins or peptides that bind to the surface of the cluster core. $1,2,3,4,5$ The theoretical background is that the formation of the ACP clusters de- 
pends on a ion activity product $\mathrm{K}_{\mathrm{S}}$ that can be defined as follows for an ACP cluster of empirical chemical formula $\mathrm{Ca}\left(\mathrm{HPO}_{4}\right)_{y}\left(\mathrm{PO}_{4}\right)_{2(1-y) / 3 . x H 2 O}$

$$
K s=a_{C a^{2+}} \cdot a_{\mathrm{HPO}_{4}^{2-}}^{y} \cdot a_{\mathrm{PO}_{4}^{-3}}^{2(1-y) / 3} \cdot a_{\mathrm{H} 2 \mathrm{O}}^{x}
$$

In the situations studied by the authors, $\mathrm{K}_{\mathrm{s}}$ is considered as an invariant so that the relative amount and composition of the solid phase can be inferred from the composition and $\mathrm{pH}$ of the fluid with which it is in equilibrium. ${ }^{1,2}$ In the very case of amorphous CaP sequestration, thermodynamically stable ACP/proteins complexes are possible because the free energy of interaction of the proteins with the amorphous material $\left(\Delta G_{\text {seq }}\right)$ is comparable to the free energy of forming the amorphous substance ( $\left.\Delta G_{\text {core }}\right)$. The equilibrium size of the nanoclusters depends on a balance of those positive and negative energy terms, both of which include water activity. And it is actually possible to relate the average radius of the core of the cluster to those two free energies, the molar volume of the ACP ( $\left.V_{\mathrm{ACP}}\right)$, and the core surface area occupied by each peptide $(A):^{1}$

$$
r_{\text {core }}=\left(-\frac{2}{3} \frac{\Delta G_{\text {seq }}}{A \Delta G_{\text {core }}}\right)\left(\frac{3 V_{A C P}}{4 \pi}\right)^{1 / 3}
$$

Until now, the vast majority of the studies about ACP sequestration by proteins were performed with model CaP suspensions in presence of low to moderate concentrations of proteins (15-30 g. $\left.\mathrm{L}^{-1}\right),{ }^{1,2,3,4}$ However, the stability of ACP clusters at high protein concentrations is an important question as some biofluids, such as milk or blood for instance, are commonly concentrated (membrane filtration) if not dehydrated (drying). In these cases, one could postulated that the extreme density of these systems may have some repercussions on the ACP/protein equilibrium and, consequently, on the properties of the final product. Indeed, in a more general context, when strong protein interactions are forced together and the available space for protein motion starts to be restricted, protein-ligand equilibrium can strongly deviates from what it is expected in more diluted samples. ${ }^{6}$

Thus, the aim of the current study is to investigate the impact of dense environment on the ability of a protein to stabilize the amorphous form of calcium phosphate. For the purpose of the study, casein is used as an example of a phosphorylated protein that is able to stabilize ACP. Such proteins display a binding sequence that are a succession of phosphoserines intercalated by glutamates. ${ }^{3}$ Caseins are found in mammalian milk in the form of casein micelles. ${ }^{1}$ Casein micelles are highly porous and "sponge like" objects of $\sim 100 \mathrm{~nm}$ in diameter, ${ }^{9}$ with a core composed of three phosphorylated caseins $\left(\alpha s_{1} ; \alpha s_{2}, \beta\right)$ that have closely related sequences (see SI for details). The associated mineral phase, often cited as an example of an amorphous calcium orthophosphate phase, ${ }^{2}$ is found in the form of spherical nanoclusters of 3.5-5.0 $\mathrm{nm}$ in diameter and spaced apart of $\sim 18 \mathrm{~nm}^{8}$

In the current work, the samples used are concentrated gels of reconstituted casein micelles from a calcium phosphocaseinate, in which the micelles are arranged in a closely-packed fashion. ${ }^{9}$ The structure and properties of the CaP phase in these samples is studied at two different casein concentrations using solid state NMR. The casein concentration is adjusted by changing the $\mathrm{H}_{2} \mathrm{O}$ content of the sample, which also has a significant effect on the interactions between the protein molecules illustrated by a tenfold increase of the osmotic pressure. ${ }^{9}$ In addition, the effect of temperature is examined by carrying out experiments at $25^{\circ} \mathrm{C}$ and $45^{\circ} \mathrm{C}$. Previous studies show that, in protein-free conditions, ACP becomes highly unstable at $45^{\circ} \mathrm{C}$ thus forming crystalline phases. ${ }^{10}$ To summarize, the objectives of these experiments are (1) to investigate the effect of molecular concentration on the CaP stability (2) to see whether or not the destabilizing effect of temperature is in some way affected by the protein concentration.

\section{EXPERIMENTAL SECTION}

Preparation of casein concentrates. The samples are made by compressing dispersions of casein micelles to concentrations above that of close-packing of the micelles. ${ }^{7,9}$ Two caseins concentration are used, namely, 300 g. $\mathrm{L}^{-1}$ and 400 g. $\mathrm{L}^{-1}$, which represent $\mathrm{H}_{2} \mathrm{O}$ contents of $78 \%$ and $71 \% \mathrm{v} / \mathrm{v}$ respectively. ${ }^{11}$ These protein concentrations surpass the casein concentration inside naturally occurring casein micelle (230 g. $\mathrm{L}^{-1}, 83 \% \mathrm{v} / \mathrm{v}$ of water, zero internal osmotic pressure). ${ }^{7,9}$ The increase in molecular interactions between these two concentrations is substantial as revealed by the rise in their osmotic pressure, from $30 \mathrm{kPa}$ to $200 \mathrm{kPa}^{7}$

Casein micelle dispersions are first prepared at $100 \mathrm{~g} . \mathrm{L}^{-1}$ from a calcium phosphocaseinate powder prepared following a procedure previously established. ${ }^{7}$ The powder is 91 $\% \mathrm{w} / \mathrm{w}$ Total Solids (TS), $85.6 \%$ TS caseins, $8.5 \%$ TS minerals and $4.6 \%$ TS non-casein protein matter. The aqueous medium used to re-hydrate the powder is an ultrafiltration permeate from skimmed milk which is classically used for the reconstitution of casein powder because it maintains the structure of the micellar assembly. ${ }^{13}$ The average ionic composition of the ultrafiltrate is: $\sim 20 \mathrm{mM} \mathrm{Na}^{+}, \sim 40 \mathrm{mM}$ $\mathrm{K}^{+}, \sim 10 \mathrm{mM} \mathrm{Ca}^{++}, \sim 30 \mathrm{mM} \mathrm{Cl}^{-}, \sim 10 \mathrm{mM}$ orthophosphate, $\sim 10 \mathrm{mM}$ citrate. In such reconstituted micelles, we estimate the concentration of colloidal $\mathrm{Ca}$ and inorganic $\mathrm{P}$ to be $0.035 \mathrm{~g} / \mathrm{g}$ of caseins and $0.014 \mathrm{~g} / \mathrm{g}$ of caseins, ${ }^{13}$ respectively, which is close to what is reported for "native" micelle. ${ }^{2}$ Concentrated samples of casein (up to 300 and 400 g. $\left.\mathrm{L}^{-1}\right)$ are obtained by concentrating the 100 g. $\mathrm{L}^{-1}$ casein micelle dispersions using the osmotic pressure technique previously described. ${ }^{7}$ In this procedure, samples are placed in dialysis bags which are immersed for a week in a solution of Polyethylene Glycol (PEG, 35 kD, Sigma-Aldrich, St. Louis, USA) in ultrafiltrate. The concentrations of PEG are chosen so that the osmotic compression of the bags leads to the desired casein concentrations in the final samples. ${ }^{7}$ These final concentrations are verified by measuring the dry matter content of a small sub-sample. Thimerosal $0.02 \%$ and sodium azide $0.1 \%$ (Sigma-Aldrich, St. Louis, USA) are added to all prepared samples to prevent bacterial growth. ${ }^{7}$ Samples are allowed to equilibrate at the temperature chosen for the experiments, i.e., $25^{\circ} \mathrm{C}$ or $45^{\circ} \mathrm{C}$ one hour before use.

Nuclear Magnetic Resonance, (NMR) experiments 
NMR conditions. Solid-State Nuclear Magnetic Resonance (ssNMR) are performed using a Bruker Avance III spectrometer (Rheinstetten, Germany) with a magnetic field of 11.7 Tesla, corresponding to $500 \mathrm{MHz}$ for ${ }^{1} \mathrm{H}$ and $202 \mathrm{MHz}$ for ${ }^{31} \mathrm{P}$. ${ }^{31} \mathrm{P}$ experiments are done using $7 \mathrm{~mm}$ and $4 \mathrm{~mm}$ standard double resonance Magic Angle Spinning (MAS) probes, with ${ }^{1} \mathrm{H}$ radio frequencies of $31 \mathrm{kHz}$ for the $7 \mathrm{~mm}$ probe and $45 \mathrm{kHz}$ for the $4 \mathrm{~mm}$. It should be noted that these irradiation frequencies are abnormally low for solid samples, probably due to the $\mathrm{H}_{2} \mathrm{O}$ conductivity of the samples. For ${ }^{1} \mathrm{H}$ experiments, a pre-saturation is used to minimize the $\mathrm{H}_{2} \mathrm{O}$ signal. The prepared casein samples are analysed at MAS spinning from 2.5 to $14 \mathrm{kHz}$ at the two concentrations 300 and 400 g. $\mathrm{L}^{-1}$ and the two temperatures 25 and $45^{\circ} \mathrm{C}$. The stability of the analysed samples is verified and confirmed by following the signal of $\mathrm{H}_{2} \mathrm{O}$ protons in a 1D ${ }^{1} \mathrm{H}$ spectrum since the peak of $\mathrm{H}_{2} \mathrm{O}$ is extremely sensitive to the temperature and the concentration of the protein. ${ }^{14}$ We note that the $\mathrm{H}_{2} \mathrm{O}$ peak of the samples at $45^{\circ} \mathrm{C}$, 300 g. $\mathrm{L}^{-1}$ at $14 \mathrm{kHz}$ displays a slow and continuous shift over several hours, indicating that in this condition the temperature of the samples is not stable (in contrast to the other conditions). Thus, such samples are not further studied.

Quantitative ${ }^{31} \mathrm{P}$ experiments are done with a $35^{\circ}$ flip angle and a relaxation delay of $10 \mathrm{~s} .{ }^{1} \mathrm{H}$ decoupling is applied only during data acquisition. For all other experiments, a flip angle of $90^{\circ}$ and a relaxation delay of $1 \mathrm{~s}$ are used. In addition, qualitative $\left\{{ }^{1} \mathrm{H}\right\}-31 \mathrm{P}$ Cross-Polarization (CP) experiments are undertaken with $1 \mathrm{~ms}$ contact time. Line broadening (LB) of ${ }^{31} \mathrm{P}$ of $100 \mathrm{~Hz}$ is used for all experiments unless otherwise indicated. Two-Dimensional Hetero-nuclear Correlation (2D HETCOR) corresponds to CP measurement with an increased delay using the StatesTPPI method. Forward linear prediction is needed on the ${ }^{1} \mathrm{H}$ dimension of HETCOR to avoid a truncation of the $\mathrm{H}_{2} \mathrm{O}$ peak. For figures 3, 4 and 6 the number of ${ }^{1} \mathrm{H}$ forward predicted points is 27,55 and 82 respectively. The ${ }^{1} \mathrm{H}$ dimension of HETCOR is treated with a sine function before applying a Fourier transformation.

The different components of each spectrum are simulated using Dmfit software, ${ }^{15}$ which allows the relative quantification of the signal of each ${ }^{31} \mathrm{P}$ species. In this semiautomatic software the user produces a simulated spectrum. The software optimizes each parameter to minimize the overall difference between the experimental and simulated spectra. This method allows the quantification of the number of ${ }^{31} \mathrm{P}$ species within an error band of $\pm 1.5 \%$ for the current quantitative spectra. The Chemical Shift Anisotropy (CSA) tensors are defined by the three usual 3 tensors $\left(\sigma_{11}, \sigma_{22}, \sigma_{33}\right){ }^{16}$

Replacing $\mathrm{H}_{2} \mathrm{O}$ by $\mathrm{D}_{2} \mathrm{O}$ in casein gels. In $\mathrm{D}_{2} \mathrm{O}$ all the labile protons are replaced by deuterons. Therefore, comparing a spectrum of $\mathrm{D}_{2} \mathrm{O}$ with that of $\mathrm{H}_{2} \mathrm{O}$ allows the distinction between signals coming from organic and inorganic species. Indeed, in a cross-polarization $\mathrm{CP}{ }^{1} \mathrm{H}-31 \mathrm{P}$ spectrum carried out on $\mathrm{D}_{2} \mathrm{O}$ labelled casein samples, the only ${ }^{31} \mathrm{P}$ species present are the ones close $(<5 \AA)$ to nonexchangeable methylene ${ }^{1} \mathrm{H}$ of the protein. Since for inorganic ${ }^{31} \mathrm{P}$ (found in the CaP clusters or present as free $\mathrm{PO}_{4}{ }^{-3}$ in solution) most of the protons that are close to them are labile protons, the ${ }^{31} \mathrm{P}$ will not display a significant signal. This is in contrast with the organic ${ }^{31} \mathrm{P}$ of the phosphoserine residues of proteins. ${ }^{16}$ These residues having three non-exchangeable covalent bonded protons attached to the organic ${ }^{31} \mathrm{P}$, the corresponding ${ }^{31} \mathrm{P}$ must display a significant signal in a $\mathrm{D}_{2} \mathrm{O}$ sample (see details in the article).

The replacement of $\mathrm{H}_{2} \mathrm{O}$ molecules by $\mathrm{D}_{2} \mathrm{O}$ within casein is performed by a technique of gas phase exchange. ${ }^{17} \mathrm{~A}$ concentrated sample of casein in $\mathrm{H}_{2} \mathrm{O}$ (300 g. $\mathrm{L}^{-1}$; osmotic pressure of $30 \mathrm{kPa}$ ) and a solution of PEG (35kD, SigmaAldrich, USA) in $\mathrm{D}_{2} \mathrm{O}$ (99.99\%) (Sigma-Aldrich, USA), at the same osmotic pressure as the one of the casein sample, are put into separate, open glass containers, which are placed next to each other in a hermetically sealed box. The two solutions (caseins in $\mathrm{H} 2 \mathrm{O}$ and PEG in $\mathrm{D}_{2} \mathrm{O}$ ) are not in direct contact, but the casein sample is able to absorb $\mathrm{D}_{2} \mathrm{O}$ vapor from the PEG solution which in turn absorbs $\mathrm{H}_{2} \mathrm{O}$ vapor from the casein solution. The exchange process lasts two days, during which the $\mathrm{PEG} / \mathrm{D}_{2} \mathrm{O}$ solution is replaced four times in order to increase the $\mathrm{D}_{2} \mathrm{O}$ content in the casein sample. The ${ }^{1} \mathrm{H}$ measurement shows that this procedure leads to the replacement of $98 \%$ of the $\mathrm{H}_{2} \mathrm{O}$ in the casein by $\mathrm{D}_{2} \mathrm{O}$. The weight of the casein sample is measured gravimetrically after these two days of $\mathrm{D}_{2} \mathrm{O}$ exchange to check if there is any (undesirable) change in casein concentration.

\section{RESULTS AND NMR ASSIGNMENTS}

In this section, the impact of casein concentration (at 300 and at 400 g. $\mathrm{L}^{-1}$ ) on the structure of the system at the atomic scale, using ${ }^{1} \mathrm{H}$ and ${ }^{31} \mathrm{P}$ NMR, is presented. The NMR results are given in three distinct sections: a first section devoted to the NMR-assignment of the different components using one given sample (that of 300 g. $\mathrm{L}^{-1}, 25^{\circ} \mathrm{C}$ ), and two sections where the structural changes induced by an increase in molecular concentration and/or temperature are presented.

1- NMR assignment of phosphorous and protons in casein gels

\section{1. ${ }^{31} \mathrm{P}$ assignment}

Assignment of bound and free ${ }^{31} \mathrm{P}$. Figure $1 \mathrm{~A}$ shows a ${ }^{31} \mathrm{P}$ quantitative spectrum of the casein sample at 300 g.L.-1 $\left(25^{\circ} \mathrm{C}\right)$, in which the NMR signal is linearly proportional to the relative abundance in $\mathrm{P}$. This spectrum is characterized by three main components: (i) an anisotropic peak that is called a CSA (chemical shift anisotropy) peak, and which corresponds to $45 \%$ of the total intensity (TI) in the spectrum; (ii) a large intense Gaussian peak (43\% of the TI; full width at half weight (fwhm) $20 \mathrm{ppm}$ ) and (iii) a less intense and narrow peak (12\% of TI; fwhm 4 ppm, at ${ }^{31} \delta 2.7$ ppm). 


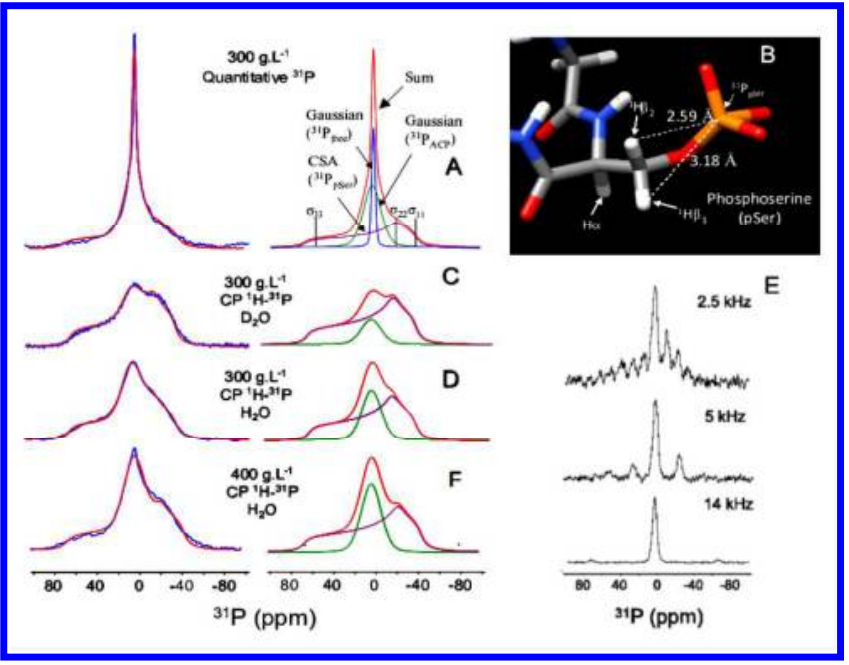

Figure 1. One dimensional ${ }^{31} \mathrm{P}$ and $\left\{{ }^{1} \mathrm{H}\right\}^{-31} \mathrm{P}$ CrossPolarization and quantitative static spectra of casein gels at $25^{\circ} \mathrm{C}$. A) Quantitative experiment of casein gel at 300 g.L $^{-1}$ in $\mathrm{H}_{2} \mathrm{O}$. The blue and red lines correspond to the experimental and simulated spectrum respectively. On the right hand side, the three components of the spectrum are displayed: a narrow Gaussian peak, ${ }^{31}{ }_{\text {Pree }}$ (blue), a broad Gaussian peak, ${ }^{31} \mathrm{P}_{\mathrm{ACP}}$ (green) and a chemical shift anisotropy (CSA), ${ }^{31} \mathrm{P}_{\mathrm{pSer}}$ component (violet). The CSA chemical shift tensors $\sigma_{11}, \sigma_{22}$ and $\sigma_{33}$ are indicated in the same Figure (see also Table 1). B) Molecular model of a phosphoserin residue $\left(\mathrm{P}_{\mathrm{Ser}}\right)$. Since the methylene proton $\beta\left(\mathrm{H} \beta_{1}\right.$ and $\mathrm{H} \beta_{2}$ ) are always physically close (between $\sim 2.6$ and $3.2 \AA)$ to the phosphorous in the organic molecule $\left({ }^{31} \mathrm{P}_{\mathrm{Ser}}\right)$ the ${ }^{1} \mathrm{H}-{ }^{31} \mathrm{P}$ interaction is expected to dominate the spectrum in $\mathrm{D}_{2} \mathrm{O}$. C and D) the CP spectra for $\mathrm{D}_{2} \mathrm{O}$ and $\mathrm{H}_{2} \mathrm{O}$ respectively (both in casein samples at a concentration of 300 g.L-1 $)$. E) NMR spectrum for a 300 g. $\mathrm{L}^{-1}$ sample in $\mathrm{H}_{2} \mathrm{O}$, at different MAS frequencies (top to bottom; 2.5, 5 and 14 $\mathrm{kHz}$ ). F) CP spectrum at 400 g. $\mathrm{L}^{-1}$.

As it has been demonstrated previously using liquid state NMR, the phosphorous in phosphoserines that are bonded to ACP clusters lead to broad NMR peaks compared to the ${ }^{31} \mathrm{P}$ in free phosphoserines; a consequence of the reduced dynamics of the bonded species. The same is true for the signal produced by inorganic ${ }^{31} \mathrm{P}$ that belong to the ACP clusters, as compared to the signal of "free" unbounded ${ }^{31} \mathrm{P}$. Thus, both peaks displaying a broad signal (i.e., the CSA and the broad Gaussian) can be assigned to either organic or inorganic ${ }^{31} \mathrm{P}$ bonded to the cluster. We will name this $\mathrm{P}$ forms "rigid $\mathrm{P}$ " in the following. In contrast, the $f w h m$ of the thin Gaussian peak shows that this peak can be readily assigned to the free ${ }^{31} \mathrm{P}$ (from both organic and inorganic species).
Table 1. ${ }^{31} \mathrm{P}$ chemical shift anisotropy (CSA) tensors and Gaussian chemical shift, found in concentrated casein gels.

\begin{tabular}{ccccccc}
$\begin{array}{c}\text { Temperature } \\
\left({ }^{\circ} \mathrm{C}\right)\end{array}$ & $\begin{array}{c}\text { Casein } \\
{\left[\mathrm{g} . \mathrm{L}^{-1}\right]}\end{array}$ & $\begin{array}{c}{ }^{31} \mathrm{P}_{\mathrm{ACP}}{ }^{*} \\
(\mathrm{ppm})\end{array}$ & \multicolumn{5}{c}{$\begin{array}{c}{ }^{31} \mathrm{P}_{\mathrm{pSer}}(\mathrm{CSA})^{* *} \\
(\mathrm{ppm})\end{array}$} \\
\hline & & Iso & Iso & $\sigma_{33}$ & $\sigma_{22}$ & $\sigma_{11}$ \\
\hline 25 & 300 & 3.1 & 2.35 & 57 & -19 & -36 \\
25 & 400 & 3.1 & 2.35 & 66 & -17 & -36 \\
45 & 300 & $7.0,3.1$ & 2.35 & 68 & -20 & -40 \\
45 & 400 & 3.1 & 2.35 & 75 & -16 & -41
\end{tabular}

${ }^{*}$ Represents the isotropic (Iso) chemical shift of the Gaussian peak. ** Represents the isotropic chemical shifts (Iso) and the CSA tensors of the CSA component. Whereas the CSA tensors were measured in static experiments the Iso are measured using MAS.

Assignments of rigid ${ }^{31} \mathrm{P}$. In order to better distinguish the different forms of phosphorous (i.e., the organic $\mathrm{P}$ of phosphoserines $\left({ }^{31} \mathrm{P}_{\mathrm{pSer}}\right)$ and the $\mathrm{P}$ of ACP $\left.\left({ }^{31} \mathrm{P}_{\mathrm{ACP}}\right)\right)$, static cross polarization (CP) experiments are undertaken both in $\mathrm{H}_{2} \mathrm{O}$ and $\mathrm{D}_{2} \mathrm{O}$ (Figures $1 \mathrm{C}-\mathrm{F}$ ). In the $\mathrm{CP}$ spectrum, the magnetization is transferred from ${ }^{1} \mathrm{H}$ to ${ }^{31} \mathrm{P}$ through space using the dipolar interaction. The peak intensity of phosphorous thus decreases with the increase of ${ }^{1} \mathrm{H}^{31} \mathrm{P}$ distance and only the phosphorous having protons that are close enough (about $5 \AA$ away) appear in the spectrum. Furthermore, in a CP experiment, the peak intensity decreases with the increase in relative mobility of the interacting nuclei (i.e. ${ }^{1} \mathrm{H}$ and ${ }^{31} \mathrm{P}$ ). For these reasons, only the signal of the ${ }^{31} \mathrm{P}$ that are very close to the bonded protons and displaying a "rigid behavior" appear in the spectrum generated by the $\mathrm{CP}$ measurements.

A first CP experiment is carried out on samples containing $\mathrm{D}_{2} \mathrm{O}$. In this case, since the phosphoserine exhibits two non-exchangeable methylene protons covalently bound to its carbon and located very close to the phosphorous ( $\sim 2.7$ and $3.1 \AA$ away for $\mathrm{H} \beta, 1$ and 2 , - Figure $1 \mathrm{~B}$ ), the ${ }^{31} \mathrm{P}_{\mathrm{pSer}}$ will display a relatively strong signal. In contrast, the phosphorous in ACP is only associated with labile protons in its close environment (from the aqueous medium or from the protein). The minimum distance between these protons and the phosphorous is estimated to be around $\sim 4.5 \AA$, which is not enough to give rise to a significant $\mathrm{CP}$ signal. ${ }^{5}$ This estimation corresponds to the smallest distance between the methylene protons of the nonphosphorylated side chains (e.g. glutamate, or basic residues as lysine and histidine) of the caseins and the ACP clusters; taking into account the fact that such protons are rather hydrophobic and are expected to be repelled by the ionic ACP clusters. In summary, the CP signal of ${ }^{31} \mathrm{P}$ per in $\mathrm{D}_{2} \mathrm{O}$ is expected to be much more pronounced than that of the ${ }^{31} \mathrm{P}_{\mathrm{ACP}}$.

The results of the $\mathrm{CP}$ experiment performed in $\mathrm{D}_{2} \mathrm{O}$ is given in Figure 1C (300 g. $\mathrm{L}^{-1}$ casein in $\left.\mathrm{D}_{2} \mathrm{O}\right)$. As expected, the thinner peak observed in Figure $1 \mathrm{~A}$ is totally absent in the CP spectrum. The CSA component dominates the spectrum $(80 \%$ of the $\mathrm{TI})$ and the large Gaussian peak is relatively minor (20\% of TI). This result indicates that the CSA 
can be assigned to ${ }^{31} \mathrm{P}_{\mathrm{pSer}}$. This assignment is further supported by the fact that the CSA displays the typical tensors values expected for ${ }^{31} \mathrm{P}_{\mathrm{pser}}$ at the $\mathrm{pH}$ of the experiment (6.8). ${ }^{16}$ On the other hand, the residual Gaussian peak present in $\mathrm{D}_{2} \mathrm{O}$ could be due to a small fraction of ${ }^{31} \mathrm{P}_{\mathrm{pSer}}$ making up the Gaussian peak and/or due to ACP phosphorous that are very close to the methylene protons of the protein. In all cases, it seems safe to assign most of the Gaussian peak obtained in the quantitative spectrum (Figure $1 \mathrm{~A}$ ) to ${ }^{31} \mathrm{P}_{\mathrm{ACP}}$. In $\mathrm{H}_{2} \mathrm{O}$, the $\mathrm{CP}$ measurement (Figure $1 \mathrm{D}$ F) produces a Gaussian peak that is slightly more pronounced $(34 \%$ of $\mathrm{TI})$ than in $\mathrm{D}_{2} \mathrm{O}(20 \%)$. This-suggests stronger interactions between the phosphorous represented by the Gaussian peak, the protons of the aqueous medium, and possibly the labile protons of the protein (e.g. $\mathrm{R}-\mathrm{OH}, \mathrm{R}-\mathrm{COOH}$ or R-NH).

To deepen the study, a NMR analysis at higher resolution, using MAS, was also performed. Using MAS, an ACP phase can be identified by its line shape which is characterized by a relatively large ( $f h w m \sim 6 \mathrm{ppm}$ ) Gaussian peak located at ${ }^{31} \delta 3$ ppm. ${ }^{18,19}$ Figure SI and $1 \mathrm{E}$ give the ${ }^{31} \mathrm{P}$ spectra obtained for the casein gels at 300 g. $\mathrm{L}^{-1}$ in $\mathrm{D}_{2} \mathrm{O}$ and in $\mathrm{H}_{2} \mathrm{O}$. At MAS 2.5 and $5 \mathrm{kHz}$, most of the intensity of the CSA component is distributed into the side bands, and one can consider that the Gaussian central peak (the most intense peak in Figure 1E) reflects mainly the ${ }^{31} \mathrm{P}_{\mathrm{ACP}}$ signal (in contrast to MAS probes set at $14 \mathrm{kHz}$, where all the CSA intensity is in the isotropic peak, Figure 1E). In the spectra from the $2.5 \mathrm{kHz}$ and $5 \mathrm{kHz}$ MAS probes, recorded both in $\mathrm{D}_{2} \mathrm{O}$ or in $\mathrm{H}_{2} \mathrm{O}$, the line width (fhwm $\sim 6 \mathrm{ppm}$ ) and the position of the ${ }^{31} \mathrm{P}_{\mathrm{ACP}}$ peak (3.1 ppm) correspond to the typical characteristics of ACP as reported previously. ${ }^{18,19}$ In contrast, the calculated shift of the isotropic peak of the CSA, which is determined using the ${ }^{31} \mathrm{P}$ of the side bands, is considerably lower, ${ }^{31} \delta 2.35 \mathrm{ppm}$. These results indicate that the Gaussian peak (in figure $1 \mathrm{~B}$ and $1 \mathrm{C}$ ) corresponds only to the phosphorous of ACP ( $\left.{ }^{31} \mathrm{P}_{\mathrm{ACP}}\right)$.

1.2. Assignments of protons interacting with Phosphoserines and ACP

Proton-Phosphorous correlation in the static state. The CP experiments demonstrate that the interaction between protons and ${ }^{31} \mathrm{P}_{\mathrm{ACP}}$ is significant. To detect the properties and to identify the nature of the protons involved (i.e. acidic or basic, whether from the protein or from the $\mathrm{H}_{2} \mathrm{O}$ molecule), a 2D NMR measurement was carried out. Figure 2 represents a $2 \mathrm{D}{ }^{1} \mathrm{H}-31 \mathrm{P}$ HETCOR static spectrum generated for a 300 g. $\mathrm{L}^{-1}$ casein sample in $\mathrm{H}_{2} \mathrm{O}\left(25^{\circ} \mathrm{C}\right)$. This static spectrum shows that most of the line widths attributed to protons are too large (broad signals $>40 \mathrm{ppm}$ ) to be studied in static state without MAS (Figure 1). One exception is the thin peak from $\mathrm{H}_{2} \mathrm{O}$ bound to the cluster at ${ }^{1} \delta 4.8 \mathrm{ppm}$ $\left({ }^{1} \mathrm{H}_{\mathrm{w}}\right.$, fwhm $\left.1.8 \mathrm{ppm}\right)$, which indicates that the dynamic of $\mathrm{H}_{2} \mathrm{O}$ is much greater than for others protons, but, as already demonstrated, rigid enough to appear in a CP spectrum. The extraction of ${ }^{31} \mathrm{P}$ slices from the 2D spectrum shows that the different types of protons (the ${ }^{1} \mathrm{H}_{\mathrm{w}}$ as well as the protons displaying the broad signals see Figure 2) correlate with the two previously assigned ${ }^{31} \mathrm{P}$ components: the CSA, ${ }^{31} \mathrm{P}_{\mathrm{pSer}}$, and the Gaussian peak, ${ }^{31} \mathrm{P}_{\mathrm{ACP}}$. The fact that $\mathrm{H}_{2} \mathrm{O}$ bound to the phosphorous of the protein displays the same chemical shift and line widths that $\mathrm{H}_{2} \mathrm{O}$ bound to the cluster, indicates that both types of $\mathrm{H}_{2} \mathrm{O}\left(\mathrm{H}_{2} \mathrm{O}\right.$ near organic or inorganic phosphorous) display the same properties in terms of dynamics and $\mathrm{H}$-bond strength. Moreover, the chemical shift of this bound $\mathrm{H}_{2} \mathrm{O}$ is very close $\left(\Delta^{1} \delta=0.05 \mathrm{ppm}\right.$ ) to that for free $\mathrm{H}_{2} \mathrm{O}$ (displayed in $\mathrm{SI}$ ) indicating that $\mathrm{H}_{2} \mathrm{O}$ molecules bound to ${ }^{31} \mathrm{P}_{\mathrm{ACP}}$, (as well as $\mathrm{H}_{2} \mathrm{O}$ bound to ${ }^{31} \mathrm{P}_{\mathrm{pSer}}$,) are in fast exchange with the free molecules in the medium. These results indicate that the $\mathrm{H}_{2} \mathrm{O}$ molecules corresponding to this signal are the ones localized in the interstitial space between the surface of the cluster and the protein, and not those that are potentially more deeply buried inside the cluster core ${ }^{18,19}$ (where the direct exchange with free $\mathrm{H}_{2} \mathrm{O}$ would probably be strongly hindered).

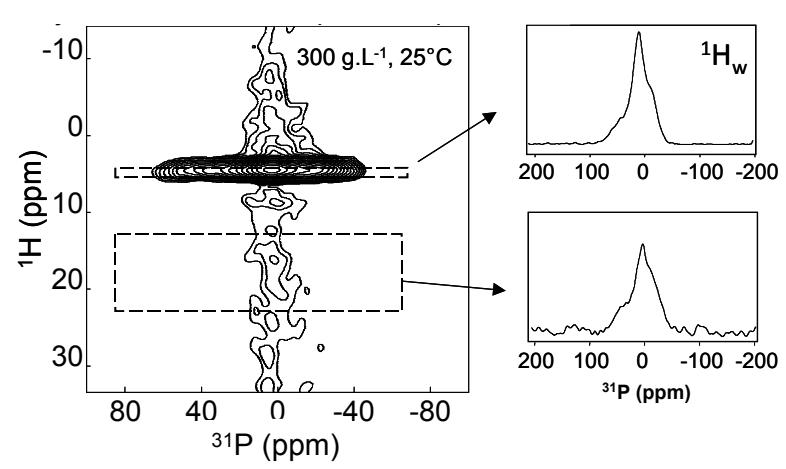

Figure 2. A $2 \mathrm{D}\left\{{ }^{1} \mathrm{H}\right\}^{-31} \mathrm{P}$ static HETCOR spectrum (300 g. $\mathrm{L}^{-1}$, $25^{\circ} \mathrm{C}$ ). The insets on the right hand side show the ${ }^{31} \mathrm{P}$ sum of slices extracted from the ${ }^{1} \mathrm{H}$ region of $\mathrm{H}_{2} \mathrm{O}$ at $4.8 \mathrm{ppm}$ $\left({ }^{1} \mathrm{H}_{\mathrm{w}}\right.$, top) and at higher ppm values (bottom).

Proton-Phosphorous correlation using MAS. Using MAS, it is possible to improve the resolution at the atomic scale. The spectrum obtained for the sample with $\mathrm{D}_{2} \mathrm{O}$ (300 g. $\mathrm{L}^{-1}$ casein, $25^{\circ} \mathrm{C}$, MAS $14 \mathrm{kHz}$ - see Figure 3) uniquely enables the detection of the signal from the non-exchangeable methylene protons. Figure 3A displays, in proton dimension, an asymmetric signal spanning from 1 to $6 \mathrm{ppm}$. Within this signal two peaks can be distinguished; a stronger peak (fwhm $2.2 \mathrm{ppm}, 1.1 \mathrm{kHz}, 75 \%$ of TI) at 4.5 ppm and a less intense proton signal spanning roughly between 1 and 3 ppm (fwhm $\sim 3$ ppm, $1.5 \mathrm{kHz}, 25 \% \mathrm{TI}$ ). 


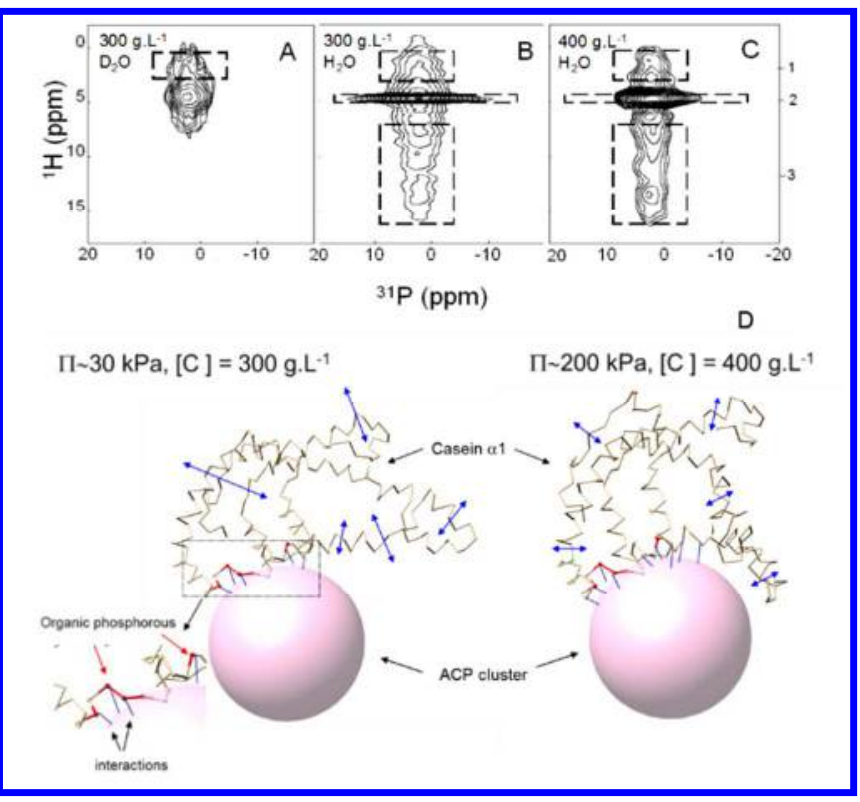

Figure 3. 2D ${ }_{1} \mathrm{H}-31 \mathrm{P}$ HECTOR measurements of casein at 300 and 400 g. $\mathrm{L}^{-1}$ in $\mathrm{H}_{2} \mathrm{O}$. The dashed squares mark out the ${ }^{1} \mathrm{H}$ regions of the methylene protons $(\mathrm{A}), \mathrm{H}_{2} \mathrm{O}$ protons (B) and labile protons (C). D) Schematic representation of the casein-ACP interaction. The size of the ACP cluster is reported in literature. ${ }^{9}$ Left, casein-ACP interaction at 300 g. $\mathrm{L}^{-1}$ (osmotic pressure, $\pi, 30 \mathrm{kPa}$ ). The red arrows (see also inset to the left) represent the interaction between ACP and organic phosphorus groups (marked in red) or different side chains of the protein. The blue arrows illustrate the motion at different regions of the casein molecule. Right, casein-ACP interaction at a concentration of $400 \mathrm{~g} . \mathrm{L}^{-1}$ (osmotic pressure, $\pi$, $200 \mathrm{kDa}$ ). The increase in molecular concentration decreases the dynamics of caseins (the blue arrows are smaller at 400 than at 300 g. $\mathrm{L}^{-1}$ ) and thus reinforces the interaction between caseins and the cluster.

The most intense peak, at ${ }^{1} \mathrm{H} 4.5 \mathrm{ppm}$, is assigned to pSer methylene $\beta_{1,2}$ protons, since its chemical shift corresponds to previously reported values ${ }^{5}$ and its correspondent $\mathrm{H}$ bond distances. ${ }^{20,21,22}$ This signal comes necessarily from the strong interaction between the proton and organic phosphorous in phosphoserine. An interaction between pSer methylene $\beta_{1,2}$ protons and the ${ }^{31} \mathrm{P}$ from ACP is unlikely since, the average distance between phosphoserine $H \beta$ and inorganic phosphorous is too great to generate a signal in CP (between 7-9 $\AA$ ). ${ }^{5}$

The chemical shift around ${ }^{1} \delta 1-3$ ppm corresponds to methylene protons $\left({ }^{1} \mathrm{H}_{\text {methyl }}\right)$ from either Arg $\mathrm{H} \gamma$, Lys $\mathrm{H} \varepsilon$, Glu $\mathrm{H} \gamma$ or Asp H $\beta$ side chains. ${ }^{5}$ The signal corresponds to the interaction between these protons and the ACP phosphorous atoms, explaining the presence of the signal of ACP previously detected in the $1 \mathrm{D} \mathrm{CP}$ spectrum in $\mathrm{D}_{2} \mathrm{O}$ (Figure 2C). Indeed, the direct interaction between the terminal groups (R-COOH or $\mathrm{R}-\mathrm{NH}_{3}$ ) of such side chains and $\mathrm{CaP}$ clusters means that the distance between their methylene protons and inorganic phosphorous atoms is small enough (3.4 to $4.4 \AA$ ) to produce a CP signal. ${ }^{5}$ For the measurements of aqueous based samples (300 g.L. $\mathrm{L}^{-1}$ casein, $25^{\circ} \mathrm{C}$, MAS $14 \mathrm{kHz}$ ) two additional peaks in addition to the ones of ${ }^{1} \mathrm{H}_{\text {methyl }}$ and serine's protons are observed (Figure 3B): a narrow (fwhm $0.4 \mathrm{ppm}, 0.2 \mathrm{~Hz}$ ) but intense $\left(\sim 30 \%\right.$ of TI) $\mathrm{H}_{2} \mathrm{O}$ peak $\left({ }^{1} \mathrm{Hw}\right)$ at ${ }^{1} \delta 4.8 \mathrm{ppm}$ (the same as in the static spectrum) and secondly, a broad peak ( $30 \%$ of TI) ranging from 8 to $16 \mathrm{ppm}$, with a maximum at around $13 \mathrm{ppm}$. In the region of methylene protons $\left({ }^{1} \mathrm{H}_{\text {methyl, }}\right.$ from 1 to $6 \mathrm{ppm}$ ) no significant difference in intensity is detected between this spectrum and the spectrum obtained for the $\mathrm{D}_{2} \mathrm{O}$ sample, indicating that all the intensity in this region $(\sim 40 \%$ of $\mathrm{TI})$ comes exclusively from the interaction between methylene protons and ${ }^{31} \mathrm{P}$. In contrast, in the ${ }^{1} \mathrm{H}$ 8-16 ppm region, all the intensity detected arises from loosely attached protons, since no signal is detected in the $\mathrm{D}_{2} \mathrm{O}$ sample.

The chemical shift signal in the 8-16 ppm region $\left({ }^{1} \mathrm{H}_{\text {lab, }}\right.$, Figure 3B) corresponds to the free or loosely attached protons forming moderate-to-strong H-bond links with phosphorus (equivalent to an average distance of $3.4 \AA$ )..$^{14}$ These $\mathrm{H}$-bonds can potentially arise from the protons in $\mathrm{H}_{2} \mathrm{O}$, R- $\mathrm{COOH}, \mathrm{R}-\mathrm{NH}_{3}{ }^{+}$(or $\mathrm{RNH}_{2}$ ) and $\mathrm{O}_{3} \mathrm{P}-\mathrm{OH}$ chemical groups which form $\mathrm{H}$-bond with orthophosphate groups. ${ }^{14}$ In reality, the loosely held protons from $\mathrm{R}-\mathrm{OH}$ groups do not display such an upfield ${ }^{1} \mathrm{H}$ shift. ${ }^{23}$ In the case of ACP, it is unlikely that direct $\mathrm{O}_{3} \mathrm{P}-\mathrm{O}-\mathrm{H}---\mathrm{O}-\mathrm{PO}_{3}$ bonds exists in the studied samples since this would imply that many orthophosphates groups are both donor and acceptor groups. According to G. Doucenet et al. (2006), ${ }^{16}{ }^{31} \mathrm{P}_{\mathrm{pser}}$ donors displaying such strong H-bonds display CSA tensors that are quite different from those found in the current work. Thus, there seems to be no significant number of ${ }^{31} \mathrm{P}_{\mathrm{pser}}$--${ }^{31} \mathrm{P}_{\mathrm{pSer}}$ or ${ }^{31} \mathrm{P}_{\mathrm{pSer}}--{ }^{31} \mathrm{P}_{\mathrm{ACP}}$ direct $\mathrm{H}$-bond interactions in the samples studied. In the same way, such strong interaction between two ${ }^{31} \mathrm{P}_{\mathrm{ACP}}$ nuclei are also quite unlikely since it would require an average distance between the orthophosphate oxygen atoms that is significantly less $(<2.6 \AA)$ than that existing between the phosphorous atoms in ACP $(>3.0 \AA) .{ }^{18}$ In the same way, previous studies have shown that free molecules with carboxylate groups, as citrate, do not display any significant affinity for the nano-clusters in the casein micelle. ${ }^{2}$ Thus, such species cannot be responsible for the observed signal. Finally, one could wonder if the $\mathrm{H}$-bond donors could be the proton in $\mathrm{H}_{2} \mathrm{O}$ molecules displaying a very strong interaction with the cluster. However, those strong bonded protons do not display a chemical shift higher than $\sim 8-9$ ppm. ${ }^{18,19}$ Thus, it is possible that the proton signal between 6 and 9 ppm comes from firmly bonded $\mathrm{H}_{2} \mathrm{O}$ protons but any signal at higher ppm values (between 10 to $16 \mathrm{ppm}$ ) definitively could not be assigned to $\mathrm{H}_{2} \mathrm{O}$. On the other hand, proteins side chains with terminal groups such as $\mathrm{R}-\mathrm{COOH}, \mathrm{R}-\mathrm{NH}_{3}{ }^{+}$or $\mathrm{R}-\mathrm{NH}_{2}$ can strongly interact with inorganic phosphorous present as colloidal phosphates. ${ }^{5,20}$ In this case, the average distance between the corresponding protein protons (from R-COOH or R$\mathrm{NH}_{3}{ }^{+}$or $\mathrm{R}-\mathrm{NH}_{2}$ ) and the inorganic ${ }^{31} \mathrm{P}$ is $\sim 3.4-3.1 \AA$, $, 5,20$ which corresponds quite well to the proton chemical shift observed in the current work ( 12 to $15 \mathrm{ppm}) .{ }^{16}$ We note that this distance is significantly greater than the average distance between the $\mathrm{H} \beta$ of serine and its phosphorous atom. As a result, these labile protons must be roughly two 
times as abundant as the $\mathrm{H} \beta$ in serine. In the casein binding sequence, the number of residues that can potentially form these interactions is about three times greater than the number of phosphoserines, ${ }^{21}$ making this estimation very reasonable.

2-Impact of molecular concentration: The rise in concentration increases the number of non-phosphorylated side chains interacting with ACP.

To investigate the impact of an increase in molecular concentration on the structure of ACP, a more concentrated sample is studied ( 400 g. $\mathrm{L}^{-1}$ of casein, $25^{\circ} \mathrm{C}$ ) and both 1D quantitative and CP measurements are performed (Figure SI and $1 \mathrm{~F}$ ). In the quantitative spectrum (figure SI) the relative intensities of the different components do not display a significant change compared to samples prepared at 300 g.L $\mathrm{L}^{-1}$ casein (Figure 1C). This suggests that, regardless of the casein concentration (300 or 400 g.L.1), there is no significant difference in the ${ }^{31} \mathrm{P}$ bound/free equilibrium (within the accuracy of the method used, that is $\sim \pm 1.5 \%$ of TI). The 1D quantitative spectra (Figure SI) and the 1D CP (Figure $1 \mathrm{~F}$ ) static spectra show that changing the concentration only induces a very small change in the CSA $\sigma_{33}$ tensor (Table 1). This small change in the spectrum is attributed to a small increase in the concentration of positively charged ions, such as calcium, in the vicinity of the phosphorous in serine. ${ }^{16}$ Indeed, the latter authors reported that an increase of the $\sigma_{33}$ tensor indicates a slight disruption of $\mathrm{H}$-bonds of ${ }^{31} \mathrm{P} \mathrm{pser}$, which is a consequence of the proximity of ionic species. The relative intensities in the $\mathrm{CP}$ experiment indicate a more significant change in the sample. The ${ }^{31} \mathrm{P}_{\text {ACP }}$ peak (Gaussian) is much more intense for samples with 400 g. $\mathrm{L}^{-1}$ casein $(41 \%$ of $\mathrm{TI})$ than those with 300 g.L $\mathrm{L}^{-1}$ (34\% of TI) (Figure 2D). This strong increase $(+20 \%)$ in the dipolar interaction between ${ }^{1} \mathrm{H}$ and ${ }^{31} \mathrm{P}_{\mathrm{ACP}}$ can either be attributed to a decrease in their mobility, or an increase in their relative proximity and/or an increase in the number of protons around each ${ }^{31} \mathrm{P}_{\mathrm{ACP}}$. In any case, these data indicate that the increase in concentration enhances the interaction between the protons and the phosphorous in the ACP clusters.

Looking at the two-dimensional ${ }^{1} \mathrm{H}-{ }^{31} \mathrm{P}$ CP-HETCOR, under MAS $14 \mathrm{kHz}$, at 400 g.L-1 of caseins (Figure 3C), one can see that the increase in the Gaussian ACP peak is related to an increase of the relative intensity of the dipolar signal in the labile proton region. Indeed, with samples at 400 g. $\mathrm{L}^{-1}$ (Figure 3B), the 2D spectrum shows a relative intensity of ${ }^{1} \mathrm{H}_{\text {lab }}$ of $40 \%$ in $\mathrm{TI}$, in contrast to $30 \%$ at 300 g. $\mathrm{L}^{-1}$ casein. On the other hand, no significant chemical shift displacement is observed in either of the two concentrations studied for any proton species. In particular, in the case of ${ }^{1} \mathrm{H}_{\mathrm{lab}}$, no change was detected in protons line widths. These data demonstrate that there is no change in the ${ }^{1} \mathrm{H}_{\text {lab }}-{ }^{31} \mathrm{P}_{\mathrm{ACP}}$ distances or in proton dynamics. Indeed, any very small change in H-bond strength (which is dependent on atomic distances and dynamics) should induce a larger change in ${ }^{1} \mathrm{H}$ chemical shift (i.e. an average change in $\mathrm{H}$-bond of only $0.05 \AA$ induces a shift of more than 2 ppm). ${ }^{14,22}$

As a consequence, the increase in the dipolar signal necessarily reflects the increase in the percentage $(+33 \%)$ of
${ }^{1} \mathrm{H}_{\text {lab }}$ protons in the protein side chains that are in the immediate vicinity of the ACP clusters. These findings suggest that, with higher molecular concentration, the effective surface of interaction between the casein proteins and the ACP clusters increases. Furthermore, the lack of change in chemical shift for $\mathrm{H}_{2} \mathrm{O}$ also means that the increase in casein concentration does not increase the number of acidic species in the interstitial space between protein micelles and the ACP clusters.

4-The impact of temperature: The increase in concentration competes with the destabilizing effect of temperature.

The above results show that the number of nonphosphorylated residues interacting with the ACP cluster increases with the increase in casein concentration. To investigate how this increase affects the stability of the clusters, the samples are submitted to a higher temperature, $45^{\circ} \mathrm{C}$. A typical characteristic of ACP, in free protein conditions, is that ACP normally becomes highly unstable at temperature above $35^{\circ} \mathrm{C}$, forming ordered crystals. ${ }^{22}$ Thus the objective of this experiment is to check on what extend casein might stabilize ACP at such higher temperatures, and how casein concentration potentially influences this stabilization.

The ${ }^{31} \mathrm{P}$ static quantitative spectra; obtained at both sample concentrations (300 and 400 g.L $\mathrm{L}^{-1}$ casein) at $45^{\circ} \mathrm{C}$ (see Figure SI in supporting information) are quite similar to those obtained at $25^{\circ} \mathrm{C}$, indicating that there is no strong change in equilibrium between bound and free phosphorous. This is in agreement with early reported results that showed that at $45^{\circ} \mathrm{C}$, the equilibrium of ${ }^{31} \mathrm{P}$ does not significantly change with respect to that at $25^{\circ} \mathrm{C} .{ }^{6}$ This same work showed that at $45^{\circ} \mathrm{C}$ the calcium content is slight increased ( 10\%). This last finding is compatible with the data from the present study since the CSA line shape of pSer displays a slight increase in the $\sigma_{33}$ tensor (300 g. $\mathrm{L}^{-1}$ casein, $45^{\circ} \mathrm{C}$, see Table 1) when increasing the temperature from $25^{\circ} \mathrm{C}$ to $45^{\circ} \mathrm{C}$. Gardinet-Doucet et al. $(2006)^{16}$ report that such an increase in the $\sigma_{33}$ tensor is indicative of a slightly closer proximity between the ${ }^{31} \mathrm{P}$ ser atoms and the calcium ions.

To test if the nanoclusters still display the typical characteristics of ACP at this higher temperature, CP spectra at low speed MAS $(2.7 \mathrm{kHz})$ are obtained. The isotropic peak observed for the sample of 300 g.L $\mathrm{L}^{-1}$ casein at $45^{\circ} \mathrm{C}$ (Figure $5 \mathrm{~A}$ ) is asymmetrical, which is the result of a left shift of about +4 ppm of part of the signal (Figure 5A, red arrow). This implies that some of the orthophosphates in the sample are localized in an environment that is quite different from that of ACP. In contrast, at the higher casein concentration of $400 \mathrm{~g}$. $\mathrm{L}^{-1}$ and at $45^{\circ} \mathrm{C}$ (Figure 5B), one observes the more typical characteristics of an ACP peak (a Gaussian like peak centered at $3.1 \mathrm{ppm}$ with $\mathrm{fwhm}$ of about 5.5 ppm). No significant differences in the relative CP intensities are observed at $45^{\circ} \mathrm{C}$ when compared to the intensities found at lower temperature $\left(25^{\circ} \mathrm{C}\right)$ for either the casein gel

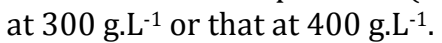




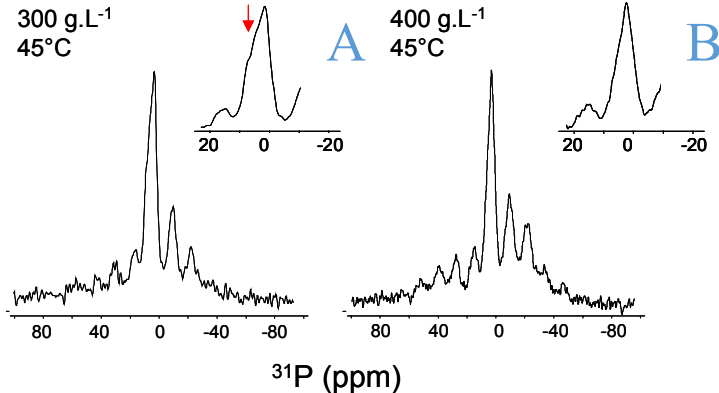

Figure 5. 1D CP $1 \mathrm{H}$ - 31P spectra of a 300 g.L-1 (A) and 400 g. $\mathrm{L}^{-1}$ (B) casein gel at $45^{\circ} \mathrm{C}$ (MAS $2.7 \mathrm{kHz}$ ). The insets show the central isotropic peak for each which is asymmetrical at 300 g. $L^{-1}$ but symmetrical at 400 g.L $L^{-1}$. At 300 g. $\mathrm{L}^{-1}$ the isotropic peak is asymmetrical, which is the result of a left shift of about +4 ppm of part of the signal pointed by the red arrow.

To find out what kind of protons exist in these non-ACP environments at $45^{\circ} \mathrm{C}$, a $2 \mathrm{D}$ experiment $\left(\mathrm{CP}{ }^{1} \mathrm{H}-{ }^{31} \mathrm{P}\right.$, MAS $2.7 \mathrm{kHz}$ ) has been performed on the $300 \mathrm{~g}$. $\mathrm{L}^{-1}$ casein sample. In proton dimension, in a 2D spectrum (Figure 6A), a spectrum qualitatively similar to the one in static conditions at $25^{\circ} \mathrm{C}$ is observed (Figure 3 ); $\mathrm{H}_{2} \mathrm{O}$ protons display a relatively narrow peak $\left({ }^{1} \mathrm{Hw}\right.$, fwhm $\left.0.9 \mathrm{ppm}\right)$ at $4.8 \mathrm{ppm}$ and the rest of the protons $\left({ }^{1} \mathrm{H}_{\mathrm{prot}}\right)$ display very broad signals spread all over the spectrum (Figure 6A).

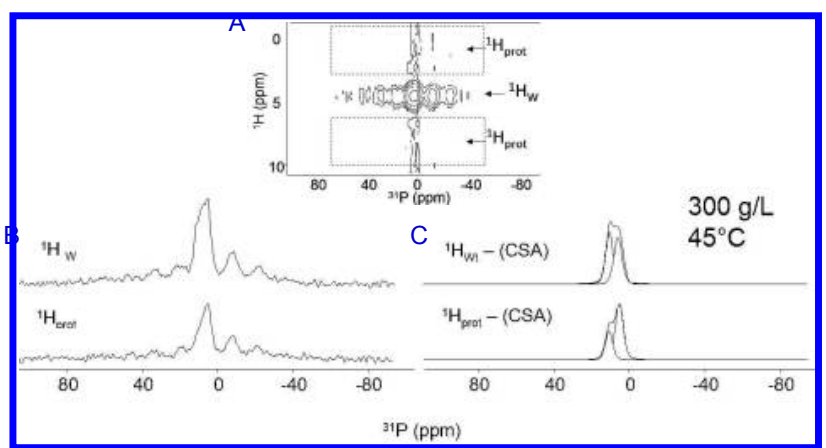

Figure 6. CP 2D ${ }^{1} \mathrm{H}-{ }^{31} \mathrm{P}$ HETCOR spectra at $45^{\circ} \mathrm{C}$ (MAS 2.7 $\mathrm{kHz}$ ) of casein gel at 300 g. $\mathrm{L}^{-1}$. (A) 2D spectrum; (B) sum of ${ }^{31} \mathrm{P}$ slices extracted from the proton regions of the $\mathrm{H}_{2} \mathrm{O}$ protons ${ }^{1} \mathrm{H}_{\mathrm{w}}$ and from the protons region of protein protons ${ }^{1}$ Hprot; (C) simulated spectrum of the central peak after extraction of the contribution of the isotropic peak and side bands of the CSA component ( $\left.{ }^{1} \mathrm{H}-(\mathrm{CSA})\right) .400 \mathrm{~g} \cdot \mathrm{L}^{-1}$ (B) casein gel at $45^{\circ} \mathrm{C}($ MAS $2.7 \mathrm{kHz})$.

Considering now the ${ }^{31} \mathrm{P}$ slices extracted from these $2 \mathrm{D}$ measurements (Figure 6C), one can see a significant difference in the line shape of the ${ }^{31} \mathrm{P}_{\mathrm{ACP}}$ between the slices correlating with ${ }^{1} \mathrm{H}_{\mathrm{w}}$ and ${ }^{1} \mathrm{H}_{\text {prot. }}$. However, no significant difference in line shape is observed in the side bands of the ${ }^{31} \mathrm{P}_{\mathrm{pSer}}$ CSA component. Figure 6C shows the respective simulated spectrum where the CSA components of the serine phosphorous (the side bands as well as the isotropic peak) are removed. In these simulated spectra one can more clearly see the presence of a peak at ${ }^{31} \mathrm{P} 7 \mathrm{ppm}$ (fwhm $4 \mathrm{ppm}$ ), that correlates better with ${ }^{1} \mathrm{H}_{\mathrm{w}}$ than with ${ }^{1} \mathrm{H}_{\text {prot. }}$ These data indicate that this non-amorphous environment is relatively abundant in the cluster (since its correlates strongly with the $\mathrm{H}_{2} \mathrm{O}$ protons) but is not located close to the protein (since the protein protons do not correlate with the non-ACP peak). The fact that this spectrum does not change after $12 \mathrm{~h}$, under low MAS, indicates that this is a stable structure and not a short-lived instability.

The same analysis on the more concentrated sample of 400 g.L $\mathrm{L}^{-1}$ at $45^{\circ} \mathrm{C}$ (see Figure-SI) shows that no such differences can be detected between slices corresponding to ${ }^{1} \mathrm{H}_{\mathrm{w}}$ and ${ }^{1} \mathrm{H}_{\text {prot. }}$ All over the spectrum, the ACP peak displays the typical characteristics of an amorphous cluster.

\section{Discussion}

In this work, the effect of high molecular concentration on the stabilizing effect of a protein on the amorphous structure of calcium phosphate is studied. The results show that, the local molecular concentration has a clear impact on the interaction between the protein and the colloidal calcium phosphate. In particular, the NMR results show that an increase in casein concentration from 300 to 400 g. $\mathrm{L}^{-1}$ increases the number of non-phosphorylated side chains of the protein that interact with the phosphate clusters. This change results in the stabilization of the disordered/amorphous structure of these clusters at $45^{\circ} \mathrm{C}$, whereas at this temperature, part of the cluster adopts an ordered structure at the lower molecular concentration (300 g.L $\left.\mathrm{L}^{-1}\right)$.

In an attempt to understand this evolution, one possibility is to come back to the description of the thermodynamics of the ACP/casein equilibrium given in the introduction (eq (1) and (2)), and see what parameters are changing and how the changes can possibly explain our results. Let us first look at water activity as $\mathrm{a}_{\mathrm{w}}$ is changed when casein concentration increases. This decrease in aw can have an impact on the free energies of sequestration and mineral core formation, and consequently modifies the number and sizes of the nanoclusters. In fact, for the casein concentrations that we use (300 and 400 g. $\left.\mathrm{L}^{-1}\right)$, the water activities are still very close to 1 (0.998 and 0.998 , respectively). This probably explains why we do not observe any observable change in size or number of the ACP nanoclusters in our results: NMR shows that the ratio of bound/free inorganic phosphorous and the CSA are not modified by casein concentration, meaning that there is no strong change in phosphorous equilibrium. So coming now to the free energy of interaction of the proteins with the amorphous material $\left(\Delta G_{\text {seq }}\right)$, the fact that more casein side chains are involved in the interaction should increase the (absolute) value of $\Delta G_{\text {seq, }}$, thus explaining why the amorphous phase is more stable at $400 \mathrm{~g} / \mathrm{L}^{-1}$ casein with respect to temperature. However this change in $\Delta G_{\text {seq }}$ is probably not sufficient (as for $\mathrm{a}_{\mathrm{w}}$ ) for changing the size of the nanoclusters in a observable manner (as predicted by eq.(2)). Moreover, it has been shown that in such restricted and denses systems, the protein-ligant equilibrium can strongly deviate from what it is expected in more diluted samples. ${ }^{6}$

One further question is now to examine if one can explain through simple arguments why the number of nonphosphorylated casein residues interacting with the clusters increases as casein concentration increases. Actually, 
excluded volume effects could play a role in this increase. Previous works in dense, pure, protein systems show that the increase in concentration induces a strong increase in protein-protein interactions ${ }^{24}$ with mainly two possible consequences: a change in protein conformation (adopting more compact conformation) and/or an increase in protein aggregation. These consequences are the response of the protein to the need of minimizing excluded volumes in dense systems. ${ }^{24}$ If such effects are important in the present system, the formation of more compact, proteincluster complexes would be favored since it would decrease the excluded volume. This effect should also counter any eventual increase in the number and/or the size of the clusters since such changes will necessarily increase the excluded volume. This is clearly consistent with our data; the observed greater number of residues from a same protein interacting with the clusters (see Figure 2) indicates a change in protein conformation that tends to form a more compact protein-shell around ACP.

\section{CONCLUSIONS}

The aim of this study is to investigate whether high molecular concentration conditions have an effect on protein stabilization of a mineral phase. For that purpose, the ability of casein to stabilize amorphous calcium phosphate phase is investigated. Our findings indicate that the increase in molecular concentration induces an increase of the surface contact area between the amorphous calcium phosphate clusters and the casein molecules. This stabilizing effect is attributed to non-specific interactions between non-phosphorylated residues of the caseins and the ACP clusters. By increasing the temperature, part of the amorphous structure of the cluster is lost. However, at this same temperature and when molecular concentration is increased, the amorphous structure is maintained. NMR results indicate that this is because more nonphosphorylated residues of the caseins are then involved in the stabilization process. Such results are probably generalizable to other dense protein systems than casein systems, where proteins interact directly with calcium phosphate in a dense environment.

\section{ASSOCIATED CONTENT}

Figures SI and the casein sequences can be found in supporting information which is available free of charge at http://pubs.acs.org

\section{AUTHOR INFORMATION}

\section{Corresponding Authors}

* Genevieve.gesan-guiziou@rennes.inra.fr

* Paulo.peresdesapeixoto@lille.inra.fr

\section{Author Contributions}

The manuscript was written through contributions of all authors. / All authors have given approval to the final version of the manuscript.

\section{ACKNOWLEDGMENT}

The authors wish to thank INRA (the French Institute for Agronomical Research) and BBA (Bretagne Biotechnologie Alimentaire - Brittany Food Biotechnology) for their financial support. They are also grateful to Thomas Croguennec for his help in preparing this paper.

\section{REFERENCES}

(1) Holt, C.; Lenton, S.; Nylander, T.; Sørensen, E. S.; Teixeira, S. C. Mineralisation of Soft and Hard Tissues and the Stability of Biofluids. J. Struct. Biol. 2014, 185 (3), 383-396.

(2) Little, E. M.; Holt, C. An Equilibrium Thermodynamic Model of the Sequestration of Calcium Phosphate by Casein Phosphopeptides. Eur. Biophvs. J. 2004, 33 (5), 435-447.

(3) Holt, C.; Sørensen, E. S.; Clegg, R. A. Role of Calcium Phosphate Nanoclusters in the Control of Calcification. FEBS J. 2009, 276 (8), 2308-2323.

(4) Holt, C.; Wahlgren, N. M.; Drakenberg, T. Ability of a Beta-Casein Phosphopeptide to Modulate the Precipitation of Calcium Phosphate by Forming Amorphous Dicalcium Phosphate Nanoclusters. Biochem. J. 1996, 314 (Pt 3), 1035-1039.

(5) Cross, K. J.; Huq, N. L.; Reynolds, E. C. Casein Phosphopeptide-Amorphous Calcium Phosphate Nanocomplexes: A Structural Model. Biochem. 2006, 55 (31), 4316-4325.

(6) Tagliazucchi, M.; Szleifer, I. How Does Confinement Change Ligand-Receptor Binding Equilibrium? Protein Binding in Nanopores and Nanochannels. J. Am. Chem. Soc. 2015, 137(39), 12539-12551.

(7) Bouchoux, A.; Cayemitte, P.-E.; Jardin, J.; GésanGuiziou, G.; Cabane, B. Casein Micelle Dispersions under Osmotic Stress. Biophvs. J. 2009, 96 (2), 693-706.

(8) de Kruif, C. G.; Huppertz, T.; Urban, V. S.; Petukhov, A. V. Casein Micelles and Their Internal Structure. $A d v$. Colloid Interface Sci. 2012, 171-172, 36-52.

(9) Bouchoux, A.; Gésan-Guiziou, G.; Pérez, J.; Cabane, B. How to Squeeze a Sponge: Casein Micelles under Osmotic Stress, a SAXS Study. Biophvs. J. 2010, 99 (11), 3754-3762.

(10) Christoffersen, M. R.; Christoffersen, J.; Kibalczyc, W. Apparent Solubilities of Two Amorphous Calcium Phosphates and of Octacalcium Phosphate in the Temperature Range 30-42 C. J. Cryst. Growth 1990, 106 (2), 349-354.

(11) Qu, P.; Bouchoux, A.; Gésan-Guiziou, G. On the Cohesive Properties of Casein Micelles in Dense Systems. Food Hvdrocoll. 2015, 43, 753-762.

(12) Gaucheron, F. The Minerals of Milk. Reprod. Nutr. Dev. 2005, 45 (4), 473-483.

(13) Famelart, M. H.; Lepesant, F.; Gaucheron, F.; Le Graet, Y.; Schuck, P. pH-Induced physicochemical modifications of native phosphocaseinate suspensions: Influence of aqueous phase. Le lait 1996, 76(5), 445-460.

(14) Limbach, H.-H.; Tolstoy, P. M.; Pérez-Hernández, N.; Guo, J.; Shenderovich, I. G.; Denisov, G. S. OHO Hydrogen Bond Geometries and NMR Chemical Shifts: From Equilibrium Structures to Geometric H/D Isotope Effects, with Applications for Water, Protonated Water, and Compressed Ice. Isr. J. Chem. 2009, 49 (2), 199-216. (15) Alonso, B.; Durand, J.-O.; Bujoli, B.; Gan, Z.; Hoatson, G. Modelling One-and Two-Dimensional Solid-State NMR Spectra. Magn Reson Chem 2002, 40, 70-76. 
(16) Gardiennet-Doucet, C.; Assfeld, X.; Henry, B.; Tekely, P. Revealing Successive Steps of Deprotonation of LPhosphoserine through ${ }^{13} \mathrm{C}$ and ${ }^{31} \mathrm{P}$ Chemical Shielding Tensor Fingerprints. J. Phvs. Chem. A 2006, 110 (29), 9137-9144.

(17) N Kuznetsova, D. C. R. Solvent Hydrogen-Bond Network in Protein Self-Assembly: Solvation of Collagen Triple Helices in Nonaqueous Solvents. Biophvs. J. 1997, 72 (1), 353-362.

(18) Combes, C.; Rey, C. Amorphous Calcium Phosphates: Synthesis, Properties and Uses in Biomaterials. Acta Biomater. 2010, 6 (9), 3362-3378.

(19) Mathew, R.; Gunawidjaja, P. N.; Izquierdo-Barba, I.; Jansson, K.; García, A.; Arcos, D.; Vallet-Regí, M.; Edén, M. Solid-State 31P and 1H NMR Investigations of Amorphous and Crystalline Calcium Phosphates Grown Biomimetically From a Mesoporous Bioactive Glass.. . Phvs. Chem. C Nanomater. Interfaces 2011, 115 (42), 20572-20582.

(20) Rimola, A.; Aschi, M.; Orlando, R.; Ugliengo, P. Does Adsorption at Hydroxyapatite Surfaces Induce Peptide Folding? Insights from Large-Scale B3LYP Calculations. J. Am. Chem. Soc. 2012, 134 (26), 10899-10910.

(21) Cross, K. J.; Huq, N. L.; Palamara, J. E.; Perich, J. W.; Reynolds, E. C. Physicochemical Characterization of Casein Phosphopeptide-Amorphous Calcium Phosphate Nanocomplexes. J. Biol. Chem. 2005, 280 (15), 1536215369.

(22) Potrzebowski, M. J.; Assfeld, X.; Ganicz, K.; Olejniczak, S.; Cartier, A.; Gardiennet, C.; Tekely, P. An Experimental and Theoretical Study of the ${ }^{13} \mathrm{C}$ and ${ }^{31} \mathrm{P}$ Chemical Shielding Tensors in Solid O-Phosphorylated Amino Acids. J. Am. Chem. Soc. 2003, 125 (14), 42234232.
(23) Abraham, R. J.; Byrne, J. J.; Griffiths, L.; Koniotou, R. ${ }^{1} \mathrm{H}$ Chemical Shifts in NMR: Part 22-Prediction of the ${ }^{1} \mathrm{H}$ Chemical Shifts of Alcohols, Diols and Inositols in Solution, a Conformational and Solvation Investigation. Magn. Reson. Chem. 2005, 43 (8), 611-624. Kuznetsova, I. M.; Turoverov, K. K.; Uversky, V. N. What Macromolecular Crowding Can Do to a Protein. Int. J. Mol. Sci. 2014, 15 (12), 23090-23140. 


\section{Page 11 of 11}

1

2

3

4

5

6

7

8

9

10

11

12

13

14

15

16

17

18

19

20

21

22

23

24

25

26

27

28

29

30

31

32

33

34

35

36

37

38

39

40

41

42

43

44

45

46

47

48

49

50

51

52

53

54

55

56

57

58

59

60

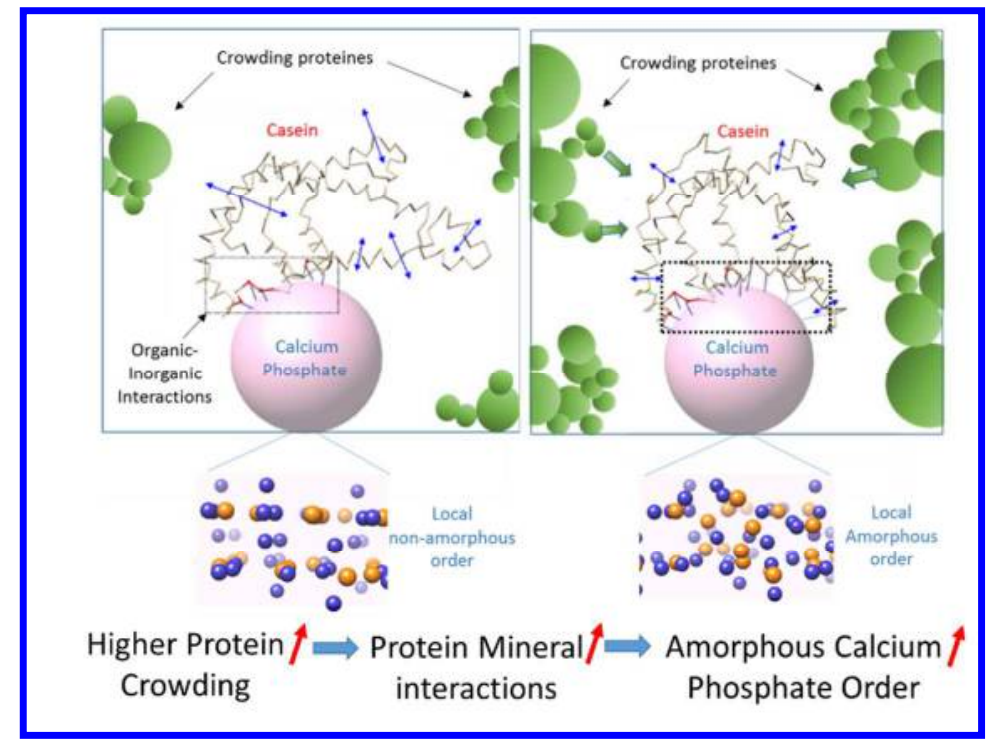

